\title{
The 1973-1978 workgroup on money of the journal 'Primo Maggio': an example of a pluralist critique of political economy
}

\author{
Stefano Lucarelli \\ Dipartimento di Scienze Aziendali, \\ Economiche e Metodi Quantitativi, \\ Università di Bergamo, \\ Via dei Caniana 2, 24127, Italy \\ E-mail: stefano.lucarelli@unibg.it
}

\begin{abstract}
The 1973-1978 workgroup on money of the Italian Workerist journal Primo Maggio aimed to change the social role of political intellectuals by innovating the methodology of historiography, sociology, economics and political science. Its research focused on the Marxian analysis of money in relation to theoretical and political impulses provided by the monetary disorder of the 1970s. The material produced by the workgroup significantly helps in creating a logical scheme which pinpoints the functions of money in a capitalist system. A link between the workgroup's reflection and the modern theory of monetary circuit is suggested. It is also explained why such a group represents an example of pluralist critique of political economy.
\end{abstract}

Keywords: monetary circuit; Workerism; non-academic research; pluralism.

Reference to this paper should be made as follows: Lucarelli, S. (2013) 'The 1973-1978 workgroup on money of the journal 'Primo Maggio': an example of a pluralist critique of political economy', Int. J. Pluralism and Economics Education, Vol. 4, No. 1, pp.30-50.

Biographical notes: Stefano Lucarelli is an Assistant Professor in Political Economy at University of Bergamo, where he teaches international monetary economics and public finance. His interests include monetary theory of production, financialisation, knowledge-based economy and the history of economic thought. He has published in a wide variety of journals including the Review of Social Economy, European Journal of Economic and Social Systems, and International Journal of Political Economy. His most recent book, written with Giorgio Lunghini, The Resistible Rise of Mainstream Economics: The Dominant Theory and the Alternative Economic Theories was published by Bergamo University Press in October 2012.

\section{Introduction}

The aim of this paper is twofold. First, to provide Anglophone readers with an account of the Italian journal Primo Maggio (May Day) workgroup on money. This group elaborated an original critique of political economy and represented an important experience in the context of social and civic struggles in Italy during the 1970s. Second, a link between the 
workgroup's reflection and the modern theory of monetary circuit is suggested and critically discussed.

In order to properly follow these two lines of inquiry, it is important to introduce some contextual elements so that the reader can correctly situate Primo Maggio's experience within the path of research and militancy known as Italian Workerism (Operaismo). As it is notorious, from the mid-1960s to 1979 Italy was traversed by a profound workers' radicality which legitimised Workerism. Such a term currently denotes a stream of Italian Marxism which emerged as a reaction to the workers' movement crisis of the second half of the 1950s. However, Workerism was not a school of economic and social theories. Rather, it was an ensemble of political experiences whose common feature was provided by a method of direct inquiry in workplaces aimed at showing conflictual potentialities on the part of subaltern classes. ${ }^{1}$ Actually, workers' conflictuality is a main element of their analyses, and consequently, practices of understanding and of organising tend to be co-existing activities.

For our purposes, it is useful to underline how Workerism, from a theoretical perspective, is considered as an unprecedented re-reading of Marx and social conflict, a re-reading which was alternative to that Marxism expressed by intellectuals belonging to the Italian Communist Party (ICP). In fact, according to Workerists, workers' struggle expresses an irreversible autonomy which is able to drive capitalist development, to reduce its role to that of an after-the-fact constant pursuit. In other words, technological as well as institutional evolutions of the capitalist system depend first and foremost on workers' struggles, and as such those developments should be conceptualised as responses to workers' conflictuality (Zanini, 2010). The Workerist experience - whose roots are generally individuated in the group of intellectuals participating in the early 1960s to the journal Quaderni Rossi (Red Notebooks) ${ }^{2}$ - was characterised by ruptures, re-compositions and new cesurae.

Against this background, the project of Primo Maggio first emerged in 1972 due to the influence of Sergio Bologna, Bruno Cartosio and Franco Mogni. The journal explicitly claims a connection with 1960s Workerism by positing the crux of its activity, the concept of militant history, whose objective is the exploration of "well-defined periods of class struggle [to emphasize the] red thread which immediately relates them to present problems". ${ }^{3}$ The journal is organised around the editorial collective Calusca, in which a prominent role is played by the charismatic book seller Primo Moroni; not by chance, the first issue sold 1700 copies, while the second reached approximately 2300 copies. However, readers were numerous and surely not limited to the movement milieux: the journal circulates in universities, prisons, and amongst Italian Central Bank's top managers [Bermani and Cartosio, (2010), pp.10-11; Bologna, (1993), p.7; Borgogno, 2010].

From the first issues, the theme of monetary control over labour represents the fundamental element investigated by the workgroup on money (hereafter the workgroup), established within the editorial board self-declaring itself to be 'at the service of the movement'. The workgroup aimed to change the social role of political intellectuals by innovating the methodology of historiography, sociology, economics and political science (Bologna, 2002). The research work focused on the Marxian analysis of money in relation to the theoretical and political impulses provided by the monetary disorder of the 1970s, with money-capital and class composition two central issues of concern. 
The language used by militant researchers can today appear as particularly complex; however, it is important to underline that such a language was, at the time, absolutely understandable. The semantic richness mobilised to revive Marxian categories was a common character of analyses in movements of workers, students and women; moreover, it represented a new modality to formulate a militant point of view. ${ }^{4}$ In Primo Maggio linguistic complexity is always accompanied by the constant search for workers' narratives: even the workgroup asks workers occupying their factories to narrate how the monetary crisis affects their everyday experience. This is the concrete meaning of a kind of research whose main goal is to establish a relation between monetary command and class composition. How is monetary command made visible? Is it an expression of the Italian Central Bank or of government's decisions? Or, does it depend on influences exercised by a superior level of command? After the collapse of Bretton Woods, who decides on the monetary availability to be conceded to a national political system? What is the role of the party system within a monetary crisis? Above all, what is the impact of monetary disorders on the working class, on productive apparatuses, and on the social transformations of the 1970s?

The main hypothesis upon which our investigation is based is: the material produced by the workgroup significantly helped to create a logical outline which pinpoints the functions of money in a capitalist system. Thus, it also constitutes a contribution to the study of the nature and functions of money in the capitalist system of production, and particularly of the theory of monetary circuit. As it is known, this conceptualisation represents an important theoretical tradition that boasts leading representatives among Italian economists depicting capitalism as a monetary production economy and focusing on the function of credit money (Graziani, 2003; Bellofiore and Seccareccia, 1999; Realfonzo, 2006). As only those who have money can access the market, the decisions made by banks about lending some people and not others money and the loan amount granted, in the opening phase of the monetary circuit become crucial factors for determining the conditions of reproduction of the system. This theory, is already present in Wicksell's and Schumpeter's works and in Keynes' Treatise on Money (Graziani, 1982). Nevertheless, the vision of the economic system as a circular production process aimed at creating money by means of money is based on Karl Marx's theory (Graziani, 1997a, 1997b). In Italy the first academic works on monetary circuit were published in the 1980s. ${ }^{5}$ It is important to acknowledge that many scholars who developed some of the most interesting studies about the endogenous theory of money were linked to Primo Maggio. ${ }^{6}$ The outline delineated from a re-reading of the workgroup's contributions is derived firstly from the Marxian interpretation of the crisis of Crédit Mobilier in France during the time of Napoleon III, as we will explain in section one. As Bologna stressed, in those articles that Marx wrote for the 'New York Daily Tribune' it is shown how the crisis is a result of political and institutional choices concerning the credit sphere. The crisis is defined as a revolution from above that interferes in working class composition in order to reduce its potential conflict. Thus, the analysis of money in these pages is linked to the new forms of capital organisation, to the new bourgeois élites which were supplanting mercantile ones, to the new forms of governance which characterise the modern State, and, finally, to class struggle.

In Sections 2, 3 and 4 we will discuss the other writings of the workgroup to show how this logical outline is able to grasp the salient aspects of the historical time initiated with the end of the Bretton Woods Agreement. In Section 5, we will analyse the difference among 'money as capital' and 'money as money' that emerges from the last 
contributions of the workgroup. Finally, in Section 6 we conclude with a discussion concerning the workgroup as an example of a pluralist critique of political economy. To verify such a hypothesis, we directly interviewed three participants to that experience (Lapo Berti, Franco Gori and Marcello Messori). Moreover, we established a long-standing debate with two other Primo Maggio authors who were directly involved in the workgroup: Bologna and Marazzi. We hope readers will forgive us for recurring too often to direct quotations or to paraphrasing. This is necessary to allow the workgroup's reflection to emerge in its richness and not, as it sometimes run the risk to labelled, as a self-referential discourse.

\section{Marx as correspondent of the 'New York Daily Tribune'}

Bologna's article Money and Crisis: Marx as Correspondent of the 'New York Daily Tribune' (Moneta e crisi: Marx corrispondente per la 'New York Daily Tribune') was published in the inaugural issue of the four-monthly journal (June-September 1973). ${ }^{7}$ The workgroup was not yet established, but the fact that the journal from its inauguration, dealt with the problem of the monetary crisis is revealing. Marx's articles for the New York Daily Tribune represented for Bologna a crucial shift to understand the economic crisis of the early 1970s. The crisis overwhelming Napoleon III's financial institutions is the topic tackled by Marx in his articles. Marx "analyses the disproportion between necessary and surplus labor" in the Bonapartist regime described as "a modern monetary system, the centralized government of liquidity [...] the actual picture of the shift from money to capital" [Bologna, (1973), p.4]. Bankers and financial aristocracy become the point of departure for Marx's analysis of capital as a whole (developed in Volume III of Capital),
"The credit system has a dual character immanent in it: on the one hand it develops the motive of capitalist production, enrichment by the exploitation of others' labor, into the purest and most colossal system of gambling and swindling, and restricts ever more the already small number of the exploiters of social wealth; on the other however it constitutes the form of transition towards a new mode of production. It is this dual character that gives the principal spokesmen for credit, from Law through to Isaac Péreire, their nicely mixed character of swindler and prophet." [Marx quoted in Bologna (1973, p.14)]

Marx analyses the Crédit Mobilier's operational mechanisms to understand the symptoms of the general convulsions of society as they manifest themselves throughout Europe in the mid 19th century. Established as a means of promoting industry and public services, the Crédit Mobilier acquired a large part of the shares in various major French companies, and had issued in their place a joint share, one common title, of its own. Thus it had, on the one hand, become the owner of a large part of French industry, and on the other, it had functioned as an element promoting a centralisation and leveling of the capitalist market "this effectively meant that it was Bonaparte's creature, enabling him to exercise control over the whole of French industry" (Ibidem, pp.4-5).

As a matter of fact, Napoleon III through the Crédit Mobilier built and spread an ideology of collective participation in the benefits of economic development in order to exploit the working class who rose up in arms in 1848. This is the reason why according to Bologna - Marx opposes Proudhon's proposal of gratuitous credit. The Proudhonist doctrine was a means to co-opt the working class within the Bonapartist 
regime. It entailed the possibility to collectively become producer-entrepreneurs, namely to govern the working class without conflict. The whole system is based on a mechanism of stock exchange speculation. The Crédit's bankers could maximally extend the bank's investments due to the privileges granted by the government so that each new industrial initiative finds at its first issue 'a premium in the Stock Exchange'.

Bologna depicts the mechanism of crisis by referring to the hypothesis advanced by Grossman, according to which the disproportionality among capitalistic sectors is to be considered the central element of Marx's theory of crisis. Bologna is aware that placing the emphasis on disproportion can lead to a 'pathogenic' political interpretation, which sees crisis as a result of failures of calculation on the part of the capitalist class. Thus, in order to grasp the working class' agency in determining the crisis, it would seem more fruitful - from a political standpoint - to stress the disproportion between necessary and surplus labour. The transformation of the mechanisms through which surplus value is extracted - introduced to co-opt the working class - allows us to grasp the real foundation for social relationships in the monetary system. Moreover, it stresses that development and crisis are indissolubly linked by an exchange relation (credit), established as a specific power which is external to, and independent from, actual producers.

"Without a disproportionate expansion of credit there could be no expansion of industrial capacity; without a disproportionate growth in the organic composition of capital there could be no increase in the mass of profit; without a disproportionate growth of the sphere of exchange, no world market; without a disproportionate increase of surplus labor no control over necessary labor.

The causes of crisis are intrinsically necessary to capitalist development."

[Bologna, (1973), p.7]

Nevertheless, monetary command is not limited to the control over necessary labour through a disproportionate increase of surplus labour. Rather, it directly affects class composition. In his article, Bologna discusses the main economic and historical variables that can help understanding the working conditions of mid-1800s workers in France. Those reports emphasise the unchanged poverty status of the French working class except for the disappearance of homeworkers - despite the revolution in the French capitalist system brought about by Péreire brothers' bank. Moreover, most French workers did not use saving banks, thus condemning to failure the project to popularise ownership through credit embarked on by Louis Napoleon.

Bologna stresses that the institutions of capitalist power are the bearer of a revolutionary project that can only be understood by accounting for the credit-led function of money. Consequently, the relationship between capital and the workforce is understandable through an analysis of institutional choices about the regulation of the concrete nature of money. Hence, special attention is paid to transformations regarding the monetary regime, since those are considered to be fundamental in order to understand the new forms of capital's organisation. It is necessary to understand - on a case-by-case basis - the relationships between the monetary system and the forms of state governance in order to give an analytical value to the evocative image of the revolution from above.

To sum, we affirm that Bologna re-read the articles Marx dedicated to the 1857 monetary crisis in France. The role of money in the context of Marx's reflection appears here as immediately linked to those credit institutions which are politically organised by the State to control and manage conflictual thrusts on the part of the emergent working class. Bologna uses a historical approach to find within the history of subaltern classes a 
confirmation of Marx's analysis as proposed in his articles. The revolution from above as performed by the capitalist State is represented by a political decision whose consequence is a modification of the money-form. The rhythms of expansion - dictated by the monetary system - appeared to Marx in 1857 as already capable to upset social as well as productive structures. Bologna's article, then, poses the following question: could Marx's work - and the context from which it emerged - offer adequate interpretative tools to understand the links between monetary disorders in the 1970s and the new configuration of class composition?

Messori stresses how the idea of revolution from above was not taken for granted,

"In Revelli's interpretation [and in mine as well] the reference to "capital's revolution from above", or "capital's plan", did not become a too oppressive and deterministic cage because it tended to expand the concept of different fractions of capital and class composition. According to us, it represented a way to recompose the different interests disseminated amongst several fractions of capital. My impression is that Sergio Bologna gave a political meaning to the expression "revolution from above". However, it was not conflicting with our view." 8

Primo Maggio is a locus of discussion and experimentation concerning interpretative categories simultaneously linked to the Marxian tradition and theoretically novel. The context is pivotal: for the workers' movement, this period is critical since Italian economic policies aimed at erasing the working class autonomy which had conquered large factories in the North during the cycle of struggles begun in 1968. For these reasons, the concept of revolution from above appears fluid and is partially independent from the development of struggle in the workplaces where the group conducts its inquiries.

The vision that characterised the workgroup is confirmed also by Marazzi (1978a, p.75):

\begin{abstract}
"Revolution from above", in that precise historical time - 1973/1974 - meant that capitalist initiative ("the great initiative") was striving to attack the kind of class composition that had produced the crisis of the early 1970s. Credit (conceived of as an attempt to socialize capital); the oil crisis (as the search for a "new" general equivalent on which to impose a capitalist adjustment of class relationships), investments in key sectors (e.g., chemistry, oil, plastic) to vertically break down the class composition: those were all topics that $\mathrm{P}$ [rimo] $\mathrm{M}$ [aggio] had identified as a ground for the historical and political analysis of the social and political movement."
\end{abstract}

Let us recall, finally, that Bologna wrote the article in 1973, in the midst of a new revolution from above characterised by currency tensions, inflation and oil crisis, goes well beyond the boundaries of the Nation-State: in August 1971 Richard Nixon declared the inconvertibility of dollar into gold.

\title{
3 Money as capital
}

The purpose of the research project set up by the workgroup was to study and describe in the broader context of world markets - a series of crisis-induced phenomena (such as inflation, crisis of the dollar, slump of the international payment system) to be configured as movements internal to monetary and credit circulation [Berti, (1978a), p.4]. At the 
same time, through inquiries in workplaces heavily affected by restructuring, the workgroup verifies the concrete applicability of categories such as revolution from above and monetary command on class composition, that is, the categories emphasised by Bologna in his unprecedented re-reading of Marx.

The workgroup was formed after changes in the editorial board of Primo Maggio [Bologna, (1993), p.10]. Berti (1978d, p.9) described two main needs of such a new, militant research,

\begin{abstract}
"On the one hand, it was about going back to one of the most distinctive elements in Marx's analysis, namely the relationship between money and crisis, and then verifying its capability to interpret the current monetary phenomena in order to provide an alternative to both the Monetarist and the Keynesian approach. On the other hand, it was about dealing directly with the analysis of the most explicit and important factors of the "monetary sphere" - such as inflation, the crisis of the international monetary system, the onset of new mechanisms of money circulation - while trying to outline an interpretation that was politically significant in a perspective of anti-capitalist struggle."
\end{abstract}

Money as Capital (Denaro come Capitale) was the first article published in Primo Maggio by Lapo Berti - although it was actually the result of a collective debate. The analysis focused on the crisis of the dollar as international currency and its consequences on the relations of production. Money is hereby meant as capital. The notion of capital does not exhaust itself in capital producing goods. Rather, it presents itself as money-capital that exhibits the different fractions of capital: money becomes money-capital and then it is transformed into productive capital only when money is lent to purchase the workforce. The movements of money through the world market represent the framework within which capital exercises its control over the working class. The working class composition - on a worldwide scale - is also the object of such a command. In other words, "money puts social relations, which are implied in its own function, at disposal of control exercised by capital over the antagonisms that found the process of production" [Berti, (1978a), p.5].

Revolution from above means here an attack on the international class composition. Therefore, it seems like a political practice consisting of a redefinition of the laws governing money circulation. As a result, money cannot be an exclusive, exact representation of wealth; rather, it must be conceived as regulated money, both at a national and at an international level. Berti (1978a, p.5), lucidly referring to the international history of money from the WWI onwards, elaborates on this point very clearly:

\begin{abstract}
"Money is no longer, if it ever was, an economic factor of the putative automatic functioning of capital, that was surreptitiously able to guarantee for itself a static measure of value, and therefore an indisputable representation of wealth. It is now "regulated" money whose value is determined according to the action of the Central Bank, as well as to the exchange relations with other currencies in the international market".
\end{abstract}

Money is command before being a measure (general equivalent)! Thereby, the declaration of inconvertibility of the dollar into gold is interpreted thus: the crisis of overproduction required a verification of value relationships between commodities at an international scale; the dollar has then reorganised its own command over the international productive structures and represented itself as the strategic commodity (i.e., oil) that leads the international trading system. However, this requirement is not 
translated into international money whose value reflects the value of particular commodities with high use-value. In the 1970s there was not a steady world market. This is demonstrated firstly by the tensions in the oil industry, which confirm the crisis of money (of any currency, not just the dollar) as a measure of value (Bologna, 1974). After Nixon's declaration, the dollar functioned as a means of payment, as paper-money on a world scale, and the creation of dollars to fund international trading follows the same laws that define the creation of bank credit: fiat money! $!^{9}$ The clear impression - fully expressed by Berti (1978c) in his reply to criticisms advanced by Suzanne de Brunhoff is that the crisis of the international monetary system cannot be understood without a strong institutional and political component being incorporated into Marx's analysis of 'objective laws'. 10

Some elements of this argument are useful to understand one of the most controversial aspects of the functioning of a monetary production economy - the determinants of the money supply. In fact, the choices regarding money creation are endogenous because they are directly linked to the capital-labour dynamics, and they turn out to be independent - regarding monetary policy - from the amount of money held by central banks, "This decoupling is due to the relationship between capital and labor, to the amount of money-salary gained through struggles, to the will to delay the final conflict between workers and capital" [Marazzi, (1978a), p.76]. In other words, the less money is convertible into gold (that is what explicitly occurs during a regime of inconvertibility of the dollar), the more it has to become convertible in terms of capitalist command over the workforce.

\section{Inflation, money supply and economic cycle}

A new way of conceptualising inflation dynamics is another original element of the workgroup's reflections. Inflation is explained as a monetary phenomenon but it is not regarded as a constant and continuous process of increase in prices level. Rather, it is considered as discontinuous temporal series of unbalancing variations that are related to capitalist development. In his article, Bologna explicitly compared 1973 in Italy with the 1850 s in France where "the chronic lack of small change and coin led to an effective increase in prices, especially on articles of working-class consumption, and accelerated the inflation process". 11

The reflections - developed in Money as Capital - on the laws governing the inflation process as an unbalancing phenomenon in the development process, start from the description of Marx's theory of the economic cycle. According to this theory, the following should happen:

1 In the ascending phase, characterised by production and market growth, there should be a progressive increase in the traditional mass of means of circulation and payment, in order to meet the increase in exchange and in prices (especially wages). This increase, in turn, is encouraged by the positive expectation of profit to fund the extension of production and to accelerate the process of realisation of surplus value.

2 In a crisis of overproduction, there should be a general fall of price level and a collapse of credit system in favour of the monetary system (which is to say: a drastic decrease in the volume of credit). 
And yet, although Italy is deeply hit by the crisis, the level of prices remains essentially steady. The workgroup's interpretation is the following: "The crisis of overproduction manifests itself in inflation rather than in a fall in the price level and the isolation of low productivity businesses. Through inflation, in fact, overproduction lies dormant as the continuity of the process of realization of surplus value is artificially guaranteed" [Berti, (1978a), p.9].

The argument can be further explained through the price equation advanced by theorists of monetary circuit, where the price level depends on the propensities to save and to invest, as well as on the level of money costs; this latter variable, in particular, explains the impact of money wages on the price level [Graziani, (2003), p.101]. The increase in propensities to consume and to invest, together with increasing money wages, pushes prices up. Each variation in the price level produces a proportional variation in the money stock, so that the money supply is endogenous. The workgroup's reflection, however, shows that variations in money supply can also be negatively correlated to price variations in case Central Bank's decisions aim at reducing monetary wages.

The issue of money supply and inflation as political instruments to suppress workers' conflict and govern capitalist development is further elaborated by Berti in an article dealing with monetary policies implemented by Banca d'Italia after 1969 (Berti, 1978b). Facing the 1968 workers' struggles against gabbie salariali, ${ }^{12}$ the Italian Central Bank enacted a series of restrictive measures, reducing the growth rate of the monetary base. The result was a progressive increase in interest rates, which led to rising tensions on the industrial credit market. The long-term goal was to revitalise dynamic competition in the manufacturing sector in order to re-establish control over the wage-variable through a boost to investments in fixed capital.
"The credit crunch and, even more so, the brutally selective management of credit, forced companies to face a drastic alternative: either they could control the workforce - that is, to ensure that the credit granted eventually reconstitutes such command through a modification in the organization of production - or they have no option but to exit the market and make room for more 'efficient' companies.” [Berti, (1978b, p.25)]

The credit crunch ended in September 1970, but more liquidity did not translate into private or public investments. Meanwhile, public spending increased revealing "a waste of money by the State" (ibidem, p.21). Traditional schemes of monetary circuit do not account for effects on productive organization that an increase in investments creates namely the qualitative change which characterises capitalist development. Similarly, such schemes do not assume a dynamic perspective within which public subsidies are accompanied by the reduction of pressures exercised by the working class on wages. To the contrary, the workgroup's analysis focused exactly on this aspect of Italian capitalism in the 1970s, which we find crucial.

The 1971 inflation represented the choice made by monetary authorities to trigger entrepreneurship, and as a result a 'drugged recovery' began. Moreover, throughout 1972 such a recovery also benefited from the devaluation of the Italian lira promoted by the Andreotti-Malagodi Government, therefore allowing an extension of the limit within which price level could increase. It also implied a political and economic evaluation of the influence of wage pressure on internal production structures; or more clearly, it is believed that the working class struggle affected the system to such an extent that it became detached from the productive levels of other industrialised countries it coexists with (ibidem, p.23). 
At the beginning of 1974, during the oil crisis, there was a return to restrictive monetary policies which made clear the attack on salaries as a situation dictated by external circumstances. Facing the increase in import costs and the impossibility to keep funding the balance of payments deficit (moving from a \$2 billion surplus in 1972 to an $\$ 8$ billion deficit in 1974) through the eurodollar market, Italy negotiated a line of credit of $\$ 1$ billion from the International Monetary Fund (IMF). The loan was subject to certain microeconomic parameters, in particular the Italian Government committed itself not to expand credit beyond a maximum limit which implied a hypothesis of growth of national income that was manifestly conducive to recession. In this case, we are faced with a form of monetary command that leads us to think about the role played by State initiative with regard to inflation processes.

\section{The reality of deficit spending}

The workgroup addressed these issues by developing an argument that examined the functions of public finance in a context of increasing inflation. Such an argument eventually led to an analysis of the State budget. Gori (1978a) was the first to deal with this subject in issue 7 of the journal. His underlying assumption is that the problems concerning the State budget deficit; the 1969 salary increase, and the actual extent of the balance of payments constraint are all aspects of a single process involving social relations and class composition as a whole (not only in Italy but in most of the advanced capitalist countries). This line of thought is developed by discussing the fiscal crisis of the State advanced by O'Connor (1973) in his famous book on the US situation. In O'Connor's dual analysis, the State guarantees the growth of large enterprises by intervening to cover all social costs produced by development itself, therefore fulfilling the essential functions of accumulation and social control. The fiscal crisis of the State represents the expression of contradictions internal to the capitalist accumulation process. Nevertheless, on the one hand the Italian situation has some specificities vis-à-vis the USA (e.g., the external constraints imposed on national economic policies); whereas on the other hand the workgroup focuses on the governance of monetary magnitudes to a greater extent than O'Connor's book:

"[In recent years, in the Italian economic system] Public spending seems [...] not so much to perform the function of providing to monopolistic industrial structures a context that is coherent with their own development logic. The crucial task is, rather, that of enforcing the form itself, of establishing the very 'possibility' of capitalist accumulation mechanisms. [...] But the crucial point of the analysis consists not so much in having identified this new political dimension in public spending activities; rather, it lies in the recognition - as economic condition that makes it feasible - of the state governance of monetary magnitudes and the credit system. [...] De facto, surplus disappears from the economic process in its traditional dimension of differential physical quantity. It reappears only as a kind of magnitude structurally related to a monetary form, as a final product of a complex economic inter-mediation that is articulated around the ways through which the state manage inflationary phenomena, devaluation policies and general credit market mechanisms" [Gori, (1978a), pp.48-49] 
It is necessary, then, to look at the decisions made by the State to control all the variables affected by inflation dynamics (international value of currency, financial return on investments, banks portfolio composition) and think about whether they have a structural nature. According to the workgroup, State initiative, through the control of monetary magnitudes, can create a funding mechanism for public spending in order to meet the social costs produced by economic growth.

However, such a growth encounters a limit in the external financial constraints. In particular, the data analysis conducted by Gori shows that the external accounts deficit is a structural problem in that it situates itself beyond a certain threshold related to the social components of public spending. This situation is determined by the fact that the Italian State has no difficulties in raising capital from the international market (central authorities fell into debt over $\$ 13$ billion between 1970 and 1975) but, as a weak economy, it is however constrained by the "politically driven external evaluation on which funding mechanisms depend" [Gori, (1978a), p.56].

The result is the following: the emergence of a welfare state on the one hand, and the creation of a new structure consolidated in the international monetary markets, on the other, have profoundly changed the role of public initiatives in regulating the economic cycle. ${ }^{13}$ State policies are therefore brought back into the money-capital cycle, whose opening phase is outside the nation-State. In this context, the main problem is not so much the monetisation of surplus value, but - to use Keynes' terminology - the creation of additional demand. Rather, the crucial issue is constituted by the need to confirm a specific form of command over salaried workers. This command is mediated by political parties according to the demands of the advanced capitalist countries that have the highest level of monetary control:
"Although on the one hand the area in which Italy - as a subsystem - is integrated would see its own financial arrangements disrupted by the unilateral declaration of insolvency, it is nonetheless able, at least in the short term, to address the problem of coherence between its social system and the structure of class relations in each country as a criterion to measure all supporting initiatives that are not economically justified ([...] during the crisis, the Christian Democrats' policy tends to delineate - beyond official statements - a feasible structure of our economy as an externally funded economy. Such a structure is meant, for stability reasons, to rely heavily on all advanced capitalist countries in the form of a specific component of their own social spending)." (ibidem, pp.56-57)

The analysis of the monetary command over class composition has, therefore, to reckon with international relations that affect economic the policy decisions at the national level. The composition of public spending is influenced by IMF within the framework of a reorganisation of international division of labour.

In order to fully understand the context in which those thoughts have emerged, it is necessary to take into account other important elements witnessed by Franco Gori:

"You have to consider that at that time we - as Primo Maggio - had an almost 'physical' perception of those aspects. Let me be clear, even though my digression risks taking a long time. The journal's editorial board used to meet up in Milan at irregular intervals - let's say more or less bimonthly - and we always had problems to find a location. This happened because our meetings tended to be open (I can't give an exact definition of this term - let's say that many people besides the members of the coordinating committee, as it was officially called, took part in them). Well, in '75-'76, at least two of those 
meetings were held at Innocenti occupied factory [...] What I felt during those meetings held at a big factory (huge spaces that exerted a strong influence on me) was the almost 'physical' dimension of the economic commitment backed up by public spending in order to maintain control of social situations like the one we found there right before our eyes!"14

In the Italian context, as Zanzani (1978) highlights, as the economic crisis became more severe, deficit spending is no longer regarded - in a Keynesian perspective - as an instrument to back up production and employment. In conjunction with an increase in tax burden on salaries, deficit spending assumes the function of "inflation multiplier". Through fiscal and budget policies, but also by centralising huge financial resources in banks which were strictly connected to the political class, the State - or, more accurately, the system of political parties that takes part in the decision-making process on which public policies depend - encouraged inflation in order to accentuate its functions as intervention and command within the economic field. In 1974, the Italian Parliament set for the first time a maximum limit for public deficit. In the same year, a major tax reform came into force, and as a result the available income was drastically reduced. In March of the same year, a strong credit crunch was implemented through the increase in the official discount rate and the introduction of a ceiling on credit expansion. Nevertheless, the inflation rate touched $20 \%$ on an annual basis. Trade unions achieved a reassessment of scala mobile (a mechanism which automatically adjusted wages to inflation) and in 1975 a single consumer price index for all workers was introduced. Entrepreneurs, who were aware that the flexible exchange rates system would have allowed appropriate manoeuvres of devaluation of the lira, did not oppose the increase in salaries. In this context, the requests of global demand contraction from IMF became increasingly pressing. 15

Under the action of a cost push inflation, which was exacerbated by national economic policies, the debt increase in the manufacturing sector is nothing else than a subtraction of income from workers:

\begin{abstract}
"A portion of wages are eroded by inflation and do not go back into businesses but, rather, goes to the distribution system, to swell the profits collected by sharks infesting the brokerage market, to increase real estate revenues, to the services sector, etc. [...] Almost all major industrial groups have conspicuous interests in the distribution sector and in the circulation of commodities and capital. [...] In this process, the State makes up for the falling of enterprise profit rate (of the whole industry) by fixing the rate through an unscrupulous spending and credit management." [Zanzani, (1978), p.64]
\end{abstract}

It emerges, therefore, the need to understand the role played by the system of political parties within the monetary circuit.

\title{
6 Money as money?
}

Between 1976 and 1977, the research of the workgroup came to a standstill. The analysis developed until then was taken up in four articles by Christian Marazzi published between 1977 and 1978. Marazzi participated in the debate on the movement of 1977 already started by Bologna. ${ }^{16}$ Facing the new forms of class resistance responding to outsourcing, Marazzi suggested that the system of political relations should act in the 
same way as capital does in its relationship with living labour. From this, a more problematic interpretation of monetary command develops:

\begin{abstract}
"In order for the political system to effectively support valorization in the same way as fixed capital does, political relations based on class do not have to be regarded as a result of exploitation but as a prerequisite of it. The anticipation of capital is in fact $\mathrm{c}+\mathrm{v}+\mathrm{p}$, where $\mathrm{p}$ is equal to the form of the political relation before the valorization process, where $\mathrm{p}=$ politics becomes a cost in the same way as variable and constant capital are. It is through the hierarchy of this "cost" of social capital that the class - social productive labor - is hierarchically divided and organized." (ibidem, p.115)
\end{abstract}

Politics is part of the anticipations necessary to capitalists so that the monetary circuit may not only open itself but also aim to develop itself economically: "any investment implies a form of political dominion that is able to control ex-ante any possible class re-composition" (ibidem, p.118). The fact that the state tries to control class behaviour in society through the role played by the system of political parties in governing income flows entails a sort of capitalist invasion of the reproduction sphere. The working class re-composition process through wage struggle is therefore undermined.

Marazzi (1977a) - in his critical review of a book by Convenevole (1977) - provides further understanding of the role played by the State in such circumstances: public spending as a political ground for restructuring income flows is essential to an expanded reproduction of labour force. Hence, by anticipations is not only meant the capital used to pay workers (ex-ante salary), but also the monetary income granted by the State to supply direct and indirect services. The distribution of real income, which is distorted by inflationary processes (on which Convenevole focuses) becomes a capitalist and Statecentred strategy:
"The State acted in two ways: on the one hand, it "freed" money in order to trigger inflation against wage rigidity (and it should not be forgotten that it happened at an international level under the regimes of universal inconvertibility and flexible exchanges that are two basic ways to remove the obstacles implied in the "relative autonomy" of monetary circulation). On the other hand, it expanded public spending in order to make the labor market more flexible. All forms of social income allocated to working class' families had precisely the function of fostering the transformation of the working class family "in synchrony" with the development of the new mode of production." (ibidem, p.118)

The link between monetary command and technological reorganisation is clear to the militant researchers as they turn their analysis to the 'diffused factory' and the post-Fordist enterprises.

It is not only about overthrowing the labour theory of value - as it occurred in Italian Workerist thought during the 1960s (particularly in the Quaderni Rossi critical sociological inquiries) - by defining the working class as a measure of capital; the crisis also concerns the relative autonomy of the circulation and reproduction spheres of the labour force. At stake is the space and time outside of the traditional locus of capitalist production. In this context, the main questions are: how to deal with class composition? How to resist this new form of revolution from above? How to set out a unit of measurement that is appropriate to those stakes? Marazzi focuses particularly on Bologna's insights as expressed in the article The Tribe of Moles, mostly dedicated to an analysis of the Italian movement of ' 77 : 


\begin{abstract}
"The State-form which presents itself today has its origins in the ideology of the crisis and in the austerity programme that this latter has brought to light. This ideology has provided the ground for establishing new, tighter relations between the parties. It is the historical basis of the Historic Compromise ${ }^{17} .[\ldots]$ It would not mean a return to the old conflictual form based the mediations negotiated by the system of parties. Rather, it would mean the restoration of the conflict between the "grass roots" and the new relationship between a socialized State-form and the production of capital. All the more so, since Jimmy Carter's imperialism - unlike the obtuse accountants of the IMF - has understood that in Italy the system of values and behaviors to which the combination of austerity measures and law-and-order has to be applied, is stronger than it appears. And therefore it is a good investment to release huge amounts of money (this is Carter's current inclination), and inject huge amounts of "command-money" through the big, private, international banking system. Let us start to turn this command into money-as-money - to transform this measure of power-over-others'-labor into power-over-our-own-needs, power over our own spaces of organization and culture, a driving-spring for the new development of a new class composition." [Bologna, (1978, p.40)]
\end{abstract}

Facing a kind of capital that - in collaboration with the system of parties - tries to squeeze socially necessary labour within the working day, class re-composition occurs via the re- appropriation of money as money, money as "class compensation for its use and consumption in order to last as a class" [Marazzi, (1977a), p.118]. Thus, Marazzi raises the issue of basic income as a measure of monetary counter power - a central aspect in the 1977 movement's claims. The 'money as money' problem became increasingly urgent, although it still needs clarification in order to avoid falling into the trap of Proudhonism, as a co-optation of the working class into the 'regime' in charge (Lucarelli and Fumagalli, 2008). Recently, Marazzi has been thinking about this issue. He has stressed the need to identify the political conditions which are necessary to avoid translating money created ex nihilo into command over living labour (subjectivity in $a c t u$ ), but rather to turn it into a means for the liberation from exploitation/valorisation processes (Marazzi and Corsani, 2007).

\title{
7 Concluding remarks: a pluralist critique to political economy
}

The debate begun with The Tribe of Moles marks the end of the workgroup's activity (Messori and Revelli, 1978; Gori, 1978b; Berti, 1978e). As a matter of fact, by reading the individual contributions it emerges as an increasingly vague reference to the "reality of struggles', and a more frantic pursuit of those subjects who are able to develop the grassroots ties necessary to resist the disintegration of the working class. It seems to us that these aspects are precisely the focus of the debate on the 1977 movement. These divisions have been accentuated by the subsequent debate on post-Fordism. But, at this point, the importance and the topicality of another line of research explored by the journal Primo Maggio emerges. We are referring to the class history, conducted through interviews and inquiries directly involving exploited subjectivities, following the hypothesis that such subjectivities might become a factor of working class' recomposition. Today, it remains of fundamental importance to understand the mode of production's process of transformation. From this perspective, the experience of the workgroup is an example of pluralist critique of political economy. Through the category of 'monetary command', the Primo Maggio workgroup produced an analysis that is fully 
part of a critical political economy. It clarified that monetary and credit policy has repercussions in terms of reorganisation of the social productive texture. It highlighted how - through a public intervention in the monetary cycle - monetary command has political implications on class composition as well. All that was also achieved by a critical (and collective) reading of official documents produced by capitalist institutions.

This represented an updating of the method of workers' inquiry as originally established by Quaderni Rossi, since it emphasised that the analysis of capitalist command on the process of production could not be limited to entrepreneurial strategies. Credit and monetary policies put forward by the Italian Central Bank - as well as the tensions pervading the international monetary system - had to be included within workers' culture. Thus, the workgroup on money of Primo Maggio engaged in a re-reading of Marxian categories by studying - together with workers in struggle problems concerning the roles of money and credit within the capital cycle. It did so in years in which the kind of Marxian terminology diffused through the movements was no longer able to account for the complexity of contemporary events and was de facto reduced to a ritual formula.

Why, then, can we talk about this experience as an example of pluralist critique of political economy? Do we find here the recognition of the legitimate existence of alternative ideologies, frameworks and references? [Reardon, (2009), p.2)] A recognition found not only in academic knowledge, but also in political knowledge produced by subjects engaged in a critique of the capitalist system of production. Academic knowledge was important in so far as its critique could make subaltern classes point of view visible. The workgroup's contributions particularly emphasised the critique of political economy, but this critique took place within a journal which criticised history, sociology, political science in order to claim centrality for direct testimonies, aspiring to build an oral history. In its 16-year long lifetime, the journal Primo Maggio was characterised by the implementation of a pluralist critique. Pluralism emerges from the creation of a critical analysis which does not exclude any discipline, but does not limit itself to it. Many movement experiences in the history of Marxism are marked by the attempt to deterministically build up the subaltern classes point of view. This happens by imposing from above an interpretative key to read the historical becoming and to provide specific subjects with a consciousness uprooted from their specificity.

In other words, Marxism is here utilised with the same organisational logic which regulates an alienating system of production. Primo Maggio represents an experience which has nothing to do with this attempt to forcibly establish an alienating hegemony. When we claim the Primo Maggio - and especially the workgroup on money which was active from 1974 to 1978 - is an example of pluralist critique of political economy, we refer to the effort to establish transparency and openness which characterised its conducting inquiries and of practicing political activism. Moreover, we contend that - in reading its materials - this pluralist effort is today more evident than ever. Being explicitly on the side of subaltern classes did not mean renouncing a pluralist stance or reducing the space for debates within the editorial board. Rather, the desire to learn and communicate - as well as to participate in the construction of subjects able to react against exploitation - occurred in a context of deep disintegration of the working class. As we have shown, Italy between 1973 and 1978 was upset by a profound industrial restructuring and by a decisive productive dislocation, whose explicit objective was the destruction of workers unity as it autonomously developed in large factories - even with regards to traditional trade unions. 
The editorial board of Primo Maggio analysed many of these occurrences, organizing struggles together with workers (at FIAT in Turin, at the harbour in Genoa, at Innocenti in Milan, and elsewhere) and enabling their voices to be directly hosted in the journal. The workgroup, until it was active, represented an important tool for education and inquiry to understand how credit and monetary policies affected the working class composition. It was not a self-referential experience, underscored by the widespread interest it generated with regard to the political and social culture of those years, both in Italy and abroad. ${ }^{18}$ Moreover, of particular relevance is the desire to open up new analytical horizons by taking seriously the problems articulated by the 1977 student movement (Bologna, 1978).

It is our conviction that the workgroup's contributions also indirectly represent a significant example of analysis in terms of monetary circuit. Retracing those contributions, it is possible to identify a research path that includes all founding ideas of the monetary circuit theory. Money has a credit nature. Money supply is endogenous. The structure of prices reflects the way in which purchasing power has been distributed in society. As a result, salaries cannot be negotiated in real terms because workers can know price levels only in a subsequent phase (Fontana and Realfonzo, 2005). Monetary policies reproduce the power asymmetries characterizing capitalism: for the group which can enjoy bank credit, in fact, money is configured economically as a source of profit, and socially as a source of power (Graziani, 2003).

The realism that inspired the workgroup directed the focus of research on a fundamental aspect neglected by Circuitists: monetary policies produce qualitative transformations in the mode of production. Using Schumpeter's terminology, we can say that credit represents the monetary complement of innovation! The result of this process is the reorganization of production that made the working-class dramatically fragmented (Fumagalli and Lucarelli, 2008). Moreover, the fact that money is regarded as a form of value which exists only in the form of a potential - because it depends on the effective implementation of monetary control over living labour - leads immediately to connect critical situations with insubordination of labour or of society. The struggles of exploited people make capitalists' profits uncertain, halt valorization of capital, show that money created ex nihilo may not result in command, and therefore may not gain the value that it potentially represents. Capitalists can react by using technological innovation to re-establish their command and make workers suffer the two-fold consequences of the uncertainty generated by themselves and the uncertainty resulting from the reorganisation of innovative processes. In this way, the systemic uncertainty to which heterodox economists refer can assume a more precise meaning.

Secondly, 'Primo Maggio' research teaches us to consider public intervention in a more complex but also more realistic perspective and not only in a Monetarist, but also in a Keynesian view. Decision-making processes concerning governments do not automatically result in public policies that reduce capitalist's interests; rather, those are institutional forms on which class exerts its own pressure - a pressure that cannot always be represented by political parties.

Thirdly, a joint reading of the workgroup's contributions provides an interpretative pattern that looks directly at the role played by the global monetary system in the regulation of class contradictions. The creation and introduction of money, in the opening phase of the monetary circuit, do not depend solely on power relations between banks and firms, but also on relationships amongst powers in the global market. The problem of the implementation - or closure of the circuit- can only be addressed in the global 
market, where money appears in its most general and developed form. It is at this level that institutional solutions, which historically have provided the regulation of the cycle, can be identified [Marazzi, (2002), pp.74-76]. ${ }^{19}$ This seems to us a great legacy on which to continue working, possibly keeping alive that desire for creating instruments of liberation from the ideologies of powers that has characterised the experience of Primo Maggio.

\section{Acknowledgements}

I am indebted to several people for discussion of these issues over the years. Most notably: Hervé Baron, Riccardo Bellofiore, Lapo Berti, Sergio Bologna, Alessandro Caiani, Roberto Ciccone, Andrea Fumagalli, Giorgio Gattei, Franco Gori, Emanuele Leonardi, Christian Marazzi, Maria Grazia Meriggi, Marcello Messori, Damiano Palano, Marco Passarella, Sergio Rossi, Carlo Vercellone, Adelino Zanini, and the Uninomade network. A previous version of the paper received the Young Scholar Award at 2010 STOREP Conference in Trento, Italy. I would like also to thank the four anonymous referees of IJPEE and to the Editor. Finally, I am grateful to Sabrina del Pico for her translation and to Emanuele Leonardi for the attentive final linguistic revision. Financial supports of MIUR ('Ricerche di Interesse Nazionale') and of Cariplo ('FYRE - Fostering Young Researchers' project) are gratefully acknowledged. The usual caveats apply.

\section{References}

Bellofiore, R. and Seccareccia, M. (1999) 'Monetary circuit', in O'Hara, P.A. (Ed.): Encyclopedia of Political Economy, pp.753-756, Routledge, London and New York.

Bermani, C. and Cartosio, B. (2010) 'Piccola storia' di una rivista', in Bermani, C. (Ed.): La rivista 'Primo Maggio' (1973-1989), pp.7-81, DeriveApprodi, Roma.

Berti, L. (1978a) 'Denaro come Capitale', Quaderno n. 2 di Primo Maggio, Supplement to Primo Maggio, No. 12, pp.3-12, Originally in Primo Maggio, September 1974, Nos. 3-4.

Berti, L. (1978b) 'Inflazione e recessione: la politica della Banca d'Italia (1969-1974)', Quaderno n. 2 di Primo Maggio, Supplement to Primo Maggio, No. 12, pp.13-27, Originally in Primo Maggio, Spring 1975, No. 5.

Berti, L. (1978c) 'Risposta a Suzanne De Brunhoff', Quaderno n. 2 di Primo Maggio, Supplement to Primo Maggio, No. 12, pp.39-45.

Berti, L. (1978d) 'Moneta, crisi e stato capitalistico: introduzione', in Berti, L. (Ed.): Moneta e crisi e stato capitalistico, pp.7-19, Feltrinelli, Milano.

Berti, L. (1978e) 'Astrattizzazione del lavoro', in Bologna, S. (Ed.): La tribù delle talpe, pp.125-139, Feltrinelli, Milano.

Berti, L. (1987) 'Alle origini della teoria monetaria contemporanea. Il contributo di Gunnar Myrdal', introduction to Gunnar Myrdal, L'equilibrio monetario, pp.7-148, Istituto della Enciclopedia Italiana fondata da Giovanni Treccani, Roma.

Berti, L. and Messori, M. (Eds.) (1996) J.A. Schumpeter, Teoria della moneta e dell'attività bancaria: capitoli inediti, Con altri scritti sulla moneta, ESI, Napoli.

Bologna, S. (1973) 'Moneta e crisi: Marx corrispondete per la New York Daily Tribune', Primo Maggio, September 1973, No. 1, pp.1-14, Translated in English in Common Sense 13 June 1993 (Part One) and 14 October 1993 (Part Two).

Bologna, S. (1974) 'Petrolio e mercato mondiale', Quaderni Piacentini, June, Vol. 13, No. 52, pp.3-27. 
Bologna, S. (1978) 'La tribù delle talpe', in Bologna, S. (Ed.): La tribù delle talpe, Feltrinelli, Milano, pp.7-40, Translated in English by E. Emery, 'The Tribe of Moles' [online] http://libcom.org/library/tribe-of-moles-sergio-bologna (accessed 26 January 2013).

Bologna, S. (1993) 'La ricerca del gruppo di Primo Maggio', preface to L. Berti and A. Fumagalli L'Antieuropa delle monete, pp.7-20, manifestolibri, Roma.

Bologna, S. (2002) Steve Wright's Storming Heaven. Class Composition and Struggle in Italian Autonomist Marxism, Translated by A. Bove, this essay first appeared in German in Sozial Geschichte and was then translated for Strategies [online] http://www.generation-online.org/t/stormingheaven.htm (accessed 26 January 2013).

Bologna, S. (Ed.) (1978) La tribù delle talpe, Feltrinelli, Milano.

Borgogno, R. (2010) 'Primo Maggio' in carcere', in Bermani, C. (Ed.): La rivista 'Primo Maggio' (1973-1989), pp.162-164, DeriveApprodi, Roma.

Convenevole, R. (1977) Processo inflazionistico e redistribuzione del reddito, introduction of A. Graziani, Torino, Einaudi.

de Brunhoff, S. (1978) 'Punti di vista marxisti sulla crisi monetaria', Quaderno n. 2 di Primo Maggio, Supplement to Primo Maggio, No. 12, pp.35-39, Originally in Politique aujourd hui, May-June 1975.

de Brunhoff, S. and Foley, D. (2006) 'Karl Marx's theory of money and credit', in Arestis, P. and Sawyer, M. (Eds.): A Handbook of Alternative Monetary Economics, pp.188-204, Edward Elgar, Cheltenham-Northampton.

Di Gaspare, S. (1982) 'Moneta e credito in Wicksell', Studi Economici, Vol. 37, No. 17, pp.47-96.

Fontana, G. and Realfonzo, R. (Eds.) (2005) The Monetary Theory of Production: Tradition and Perspectives, Palgrave-Macmillan, Basingstoke and New York.

Frattianni, M. and Savona, P. (1972) La liquidità internazionale. Un proposta per la ridefinizione del problema, Il Mulino, Bologna.

Fumagalli, A. and Lucarelli, S. (Eds.) (2008) 'Money and technological change: the role of financing in the process of evolution', European Journal of Economic and Social Systems, Special Issue, No. 2, Vol. 21, Hermes-Lavoisier, Paris.

Gori, F. (1978a) 'Per una ricerca sul bilancio dello stato', Quaderno n. 2 di Primo Maggio, Supplement to No. 12 of Primo Maggio, pp.46-58, Originally in Primo Maggio, Autumn 1976, Vol. 6, No. 7, pp.11-24.

Gori, F. (1978b) 'Chi scava che cosa', in Bologna, S. (Ed.): La tribù delle talpe, pp.107-124, Feltrinelli, Milano.

Graziani A. (1982), 'L'analisi marxista e la struttura del capitalismo moderno', in VV.AA. (Ed.): Storia del marxismo, Vol. 4, pp.702-741, Torino, Einaudi.

Graziani, A. (1997a) 'Moneta e credito nella teoria marxiana', in Graziani, A. (Ed.): I conti senza l'oste. Quindici anni di economia italiana, pp.223-234, Translated in English 'The Marxist theory of money', in Bellofiore, R. (Ed.): International Journal of Political Economy, Summer, Special Issue, Vol. 27, No. 2, pp.26-50.

Graziani, A. (1997b) 'Riabilitiamo la teoria del valore', in Graziani, A. (Ed.): I conti senza l'oste. Quindici anni di economia italiana, pp.235-240, Translated in English 'Let's rehabilitate the theory of value', in Bellofiore, R. (Ed.): International Journal of Political Economy, Summer 1997, Special Issue, Vol. 27, No. 2, pp.21-25.

Graziani, A. (2001) Lo sviluppo dell'economia italiana. Dalla ricostruzione alla moneta europea, Bollati Boringhieri, Torino.

Graziani, A. (2003) The Monetary Theory of Production, Cambridge University Press, Cambridge.

Lotringer, S. and Marazzi, C. (Eds.) (2007) Autonomia. Post-Political Politics, Semiotext(e)-MIT Press, Los Angeles-Cambridge Mass. and London.

Lucarelli, S. and Fumagalli, A. (2008) 'Basic income and productivity in cognitive capitalism', Review of Social Economy, March, Vol. 66, No. 1, pp.71-92. 
Marazzi, C. (1977a) 'Commento a Convenevole', Primo Maggio, Winter 1977-1978, Vol. 9, No. 11, pp.28-34.

Marazzi, C. (1977b) Money in the World Crisis: The New Basis of Capitalist Power, Autumn, Vol. 2, No. 2, pp.91-111, Zerowork.

Marazzi, C. (1978a) 'Alcune proposte per un lavoro su 'denaro e composizione di classe', Quaderno n. 2 di Primo Maggio, Supplement to No. 12 of Primo Maggio, pp.75-80.

Marazzi, C. (1978b) 'Il dollaro senza qualità', Primo Maggio, Winter 1977-1978, Vol. 10, No. 12, pp.30-34.

Marazzi, C. (1978c) 'La crisi del doppio mulinello', in Bologna, S. (Ed.): La tribù delle talpe, pp.82-94, Feltrinelli, Milano, Originaly in Primo Maggio, Winter 1977-1978, Vol. 8, Nos. 8-9, pp.113-118.

Marazzi, C. (2002) 'Denaro e guerra', in Fumagalli, A., Marazzi, C. and Zanini, A. (Eds.): La moneta nell'impero, preface by T. Negri, Verona, ombre corte, pp.41-98.

Marazzi, C. (2008) Capital and Language, Semiotext(e)-MIT Press, Los Angeles, Cambridge Mass. and London.

Marazzi, C. and Corsani, A. (2007) 'Biorevenu et resocialisation de la monnaie', Multitudes, Winter, Vol. 27, No. 27, pp.37-42.

Marx, K. (1856/1980) 'The monetary crisis in Europe', New York Daily Tribune, 15 October, now in Marx, K. and Engles, F. (Eds.): Collected Works, Vol. 15, Progress Publishers, Moscow.

Messori, M. (1980) 'Gli aspetti monetari di Wicksell', Materiali CNR, CNR, Napoli.

Messori, M. (1983a) 'Moneta senza crisi: un commento', Materiali filosofici, gennaio-aprile, No. 7, pp.113-156.

Messori, M. (1983b) 'La sequenza Marx-Schumpeter-Keynes: cenni introduttivi', in VV.AA. (Ed.): Keynes, pp.67-84, CRT, Torino.

Messori, M. (1984) 'Teoria del valore senza merce denaro. Considerazioni preliminari sull'analisi monetaria di Marx', Quaderni di storia dell'economia politica, Vol. 2, Nos. 1-2, pp.185-232, Translated in English 'The theory of value without commodity money? Preliminary considerations on Marx's analysis of money', in Bellofiore, R. (Ed.): International Journal of Political Economy, Summer 1997, Special Issue, Vol. 27, No. 2, pp.51-96.

Messori, M. (Ed). (1988) Moneta e Produzione, with introduction by A. Graziani, Einaudi, Torino.

Messori, M. and Revelli, M. (1978) 'Centralità operaia', in Bologna, S. (Ed.): La tribù delle talpe, pp.41-81, Feltrinelli, Milano.

Moroni, P. and IG Rote Fabrik, Kontzeptbüro (Eds.) (1999) Le parole e la lotta armata. Storia vissuta e sinistra militante in Italia, Germania e Svizzera. Materiali tratti dal Convegno di Zurigo 'Zwishenberichte', 1997, ShaKe Edizioni, Milano.

O'Connor, J. (1973) The Fiscal Crisis of the State, St. Martin Press, New York.

Realfonzo, R. (2006) 'The Italian circuitist approach', in Arestis, P. and Sawyer, M. (Eds.): A Handbook of Alternative Monetary Economics, pp.105-120, Cheltenham-Northampton, Edward Elgar.

Reardon, J. (2009) 'Foreword', International Journal of Pluralism and Economics Education, Vol. 1, Nos. 1-2, pp.1-6.

Roth, K.H. (2010) 'La rivista 'Primo Maggio' nella terza fase dell'operaismo (1973-1988)', in Bermani, C. (Ed.): La rivista 'Primo Maggio' (1973-1989), pp.82-110, DeriveApprodi, Roma.

Tarrow, S. (1989) Disorder and Democracy: Conflict, Protest and Political Change in Italy, Clarendon Press, Oxford.

Tronti, M. (1964/2006) Operai e Capitale, DeriveApprodi, Roma.

Vercellone, C. (1996) 'The anomaly and exemplariness of the Italian welfare state', in Virno, P. and Hardt, M. (Eds.): Radical Thought in Italy, pp.80-95, University of Minnesota Press, Minneapolis-London. 
Wright, S. (2002) Storming Heaven: Class Composition and Struggle in Italian Autonomist Marxism, Pluto Press, Translated in Italian (2008) L'assalto al cielo. Per una storia dell'operaismo, with afterword by R. Bellofiore e Massimiliano Tomba, Edizioni Alegre, Roma.

Wright, S. (2008) 'Revolution from above? Money and class composition in Italian operaismo', presented at the 5th annual Historical Materialism Conference, School of Oriental and African Studies, London, 7-9 November.

Zanini, A. (2005) Filosofia Economica. Fondamenti economici e categorie politiche, Torino, Bollati Boringhieri, Translated in English by Orsi, C. (2008) Economic Philosophy: Economic Foundations and Political Categories, Peter Lang, Frankfurt am Main.

Zanini, A. (2010) 'On the 'philosophical foundations' of Italian Workerism: a conceptual approach', Historical Materialism, Vol. 18, No. 4, pp.39-63.

Zanzani, M. (1978) 'La crisi e i suoi miti', Quaderno n. 2 di Primo Maggio, Supplement to No. 12 of Primo Maggio, pp.60-66, Originally in Primo Maggio, Spring 1977, No. 8, pp.19-25.

\section{Notes}

1 We are aware that the word 'conflictuality' constitutes a neologism in English, but the word 'opposition' is misleading since it does not clearly express the primacy of workers' conflict over capitalist restructuring. The word 'conflictuality', then, is used here to signify the basic assumption of Italian Workerism, namely that class struggle is the driving force of both technological innovation and institutional development. The definitive form of this assumption comes from a well-known passage written by Tronti (1964/2006, p.39): "We too have worked with a concept that puts capitalist development first, and workers second. This is a mistake. And now we have to turn the problem on its head, to change perspective and start again from the beginning: and the beginning is the class struggle of the working class. At the level of socially developed capital, the capitalist development is subordinate to workers' struggles, comes after them and on them it has to build the political mechanism of its own production".

2 Raniero Panzieri, Romano Alquati, Alberto Asor Rosa, Massimo Cacciari, Gaspare De Caro, Rita Di Leo, Antonio Negri, Vittorio Rieser, Marito Tronti, among others.

3 See the back cover of issue 1 of the journal, written by Bologna. See also Bermani and Cartosio (2010).

4 This difficulty has been explicitly recognised by Wright (2008). It should be recalled that, at the time, Marazzi's (1977b) text represented an attempt to share with the Anglophone world some reflections elaborated by Italian political movements (especially the links between monetary disorders and re-organisation of the working class). Italian movements' political thinking from 1968 to 1980 keeps soliciting a relevant interest, one of the reasons being the state's repression against such movements - surreptitiously accused to practice and foster armed struggle. See Tarrow (1989) and Lotringer and Marazzi (2007). For a non-mystified analysis of Italian armed formations and their critiques to capitalism, see Moroni and IG Rote Fabrik, Kontzeptbür (1999).

5 Ding this time Augusto Graziani organised a workshop on monetary theory hosted by the Department of Economics at the University of Naples. Among the attendees were Marcello Messori and Lapo Berti who shared the Primo Maggio experience. Among the most interesting accounts of that experience is a collection of essays in Messori (1988).

6 Andrea Battinelli, Lapo Berti, Sergio Bologna, Franco Gori, Christian Marazzi, Mario Zanzani were the backbone of the workgroup on money, from 1974 to 1978. Fabio Arcangeli, Marcello Messori, Serena Di Gaspare e Roberta Bartolini also were part of the workgroup for a shorter period of time. C.f., Bologna (1993, p.10), Wright (2008), Zanini (2005, Ch. 2). Concerning the most important contributions advanced by scholars of the Primo Maggio experience to the literature on endogenous money and the monetary theory of production, see: Messori (1988), Berti (1987), Di Gaspare (1982), Messori (1980, 1983a, 1983b, 1984), and Berti and Messori (1996). 
7 It also constitutes the first part of a longer essay published in 1974 in S. Bologna, P. Carpignano, A. Negri, Crisi e organizzazione operaia, Feltrinelli. See also Marx (1856/1980). Bologna consulted at Fondazione Feltrinelli the microfilms of 'New York Daily Tribune' and other rare materials referring to debates about money in Marx's time.

8 Interview granted to the author in Milan, at Bocconi University, on May 20, 2009.

9 From the 1960s onwards, central banks - followed by private and international banks - started to redeposit part of their dollar reserves outside the USA. It produced a series of accounting records denominated in US currency and kept mainly by European banks (hence the term eurodollars). The US bank operated de facto as the central bank of the international monetary system. C.f. Frattianni and Savona (1972).

10 It is not possible here to properly analyse the debate between de Brunhoff and Berti about the use of Marx's theory of money to interpret the monetary crises of the 1970s. It is nonetheless necessary to recall that de Brunhoff considers Primo Maggio's point of view as a sort of recuperation of certain notions which were typical of bourgeois political economy. See de Brunhoff (1978). On de Brunhoff's perspective on Marx's theory of money and credit, see de Brunhoff and Foley (2006).

11 Bologna (1973, p.11).

12 A system that allowed firms to set different wages for similar workers in different regions (South and North).

13 On this point see also Vercellone (1996).

14 Interview granted to the author in Florence, at the Department of Mathematics for Decisions, on May 23, 2009.

15 Graziani (2001, pp.125-127).

16 See Marazzi (1977a, 1978a, 1978b, 1978c), Bologna (1978), and Wright (2002, Ch. 9).

17 The Historic Compromise (Italian: Compromesso storico) was an accommodation between the Christian Democrats (DC) and the PCI in the 1970s. The 1978 assassination of DC leader Aldo Moro put an end to the Compromesso storico.

18 Even after the end of the workgroup, its analyses were wide studies. For example, publishing house Feltrinelli released a volume of the series 'Opuscoli marxisti' which contained some of the articles as well as new materials (Berti, 1978d). Moreover, it is important to recall that the theses elaborated by the workgroup reached a broader, international audience due to journals like 'Zerowork', 'Autonomie - Materialen gegen die Fabrikgesellschaft', as well as through the influence exercised in France by de Brunhoff. See de Brunhoff (1978), Marazzi (1977b), and Roth (2010, p.83).

19 For an English translation, see Marazzi (2008). 